\title{
The Power of Turkey Diplomacy in Transfer of Function of Hagia Sophia to be a Mosque
}

\author{
Hendra Maujana Saragih ${ }^{1}$, Meinita Hasya Eka Wulandari², Sri Issundari3 \\ 1,2Universitas Nasional, Jakarta, Indonesia, Indoneisa \\ ${ }^{3}$ Universitas Pembangunan Nasional, Yogyakarta, Indonesia \\ hendramaujana@gmail.com, meinita2105@gmail.com (correspondence), \\ sri.issundari@upnvyk.ac.id
}

\begin{abstract}
This paper aims to explain how aggressive the Turkish movement is under Erdogan's leadership and the domination of the ambitious AKP in an effort to restore the glory of Islam and spread its spirit of struggle on Turkish soil amidst secularism that has deeply rooted itself to dominate every aspect of life there. The synergy between the two slowly led to rivalries between authoritarian secularism and democratic nationalism with a touch of moderate Islamic nuances and Neo-Ottomanism which prioritized the freedom and welfare of the people, as well as reviving the power of the Ottoman Empire in a region that had previously entered its expansion area. Erdogan's actions, influenced by his life background, finally realized diplomacy in the form of Islamization in the form of changing the function of Istanbul's holy building, the Hagia Sophia, into a mosque while strengthening Erdogan's influence and Turkey's position in the international political arena, thus changing the direction of domestic policy as well as Turkish foreign policy despite steps This is also considered a controversial one-sided decision and poses a potential threat to peace in one's own country.
\end{abstract}

Keywords: Erdogan, Turkey, Hagia Sophia, Diplomacy

\section{Introduction}

International relations is about every event in the world that occurs across national boundaries and is constructed so that it becomes a series of studies that can explain, define, predict and predict phenomena that occur in the world with a repeating pattern. Within it are many layers of community, from ordinary individuals to the level of a sovereign state. ${ }^{1}$

The discussion of religion and all its kinds has been a very sensitive subject in the world. Often times an individual or a large group of people and

1Robert Jackson dan Georg Sorensen, Pengantar Studi Ilmu Hubungan Internasional: Teori Dan Pendekatan, 5th ed. (Yogyakarta, Daerah Istimewa Yogyakarta: Pustaka Pelajar, 2016). 
even countries in the world have disagreements about this issue. The problem of friction or conflict over religion is not separated from the study of international relations, because things like this have been ingrained and constructed in the history of our lives.

It can be said that religion is often a "commodity" in the dynamics of international politics. Religion also affects the political agenda, both individuals and groups within a country. All parties confuse both their interests and the interests of the state with religious aspects, even though it is clear that problems related to political matters and discussion of religion always clash with one another.

For example, the dynamics of the development of Europe in medieval times was not just a matter of sharp geographical or territorial boundaries that distinguished each independent state, but this complex issue was widespread, mixed, and confusing because power and power were simultaneously regulated on the basis of religion and politics. The medieval era is also one of the eras where chaos, disorder, conflict, and violence stemming from the absence of control and political organization of the region are rife.

Sometimes, war is a battle between religious civilizations, such as the Crusades against the Islamic world in the period 1096-1291, which then marks the beginning of the emergence of a 'trend' of war with religious themes that can even last for hundreds of years, as has been recorded. in history, namely the crusade which also witnessed the history of the seizure of Constantinople and the Hagia Sophia in Turkey.

Turkey, a country with an area of approximately 814,578 square kilometers, is one of the unique countries because its territory is between two continents, namely the continents of Asia and Europe, with a composition of $97 \%(790,200$ square $\mathrm{km})$ of each area located on the Asian continent. and the remaining $3 \%(24,378 \mathrm{sq} \mathrm{km})$ is located on the European continent. This strategic geographical position makes Turkey seen as an "adhesive" bridge between the differences that exist in the East and West. Historically, the Turks inherited the Roman, Islamic, Arab and Persian civilizations which were part of the heyday of the Ottoman Empire and the influence of modern Western countries. $^{2}$

\footnotetext{
2Ade Solihat, "Kemalisme, Budaya dan Negara Turki", on http://www.fib.ui.ac.id
} 
Islamic civilization with Arab and Persian influences became a legacy for Turkish society, where during the time of the Caliphate, Islam was implemented as a religion that regulates the relationship between humans as creatures and Allah SWT as the Creator; and also a social system that underlies social and state life. ${ }^{3}$ The Islamic civilization adopted by Turkey before being touched by the Western world made the Sultan the caliph. This means that as a leader of the state, as well as holding a position as a religious leader. ${ }^{4}$

Islam from Persian influence, developed in the territory of the Turkish Caliphate and showed a strong influence on Turkish culture. Furthermore, due to geographic influence, modernization has become indisputable and Turkey has also absorbed elements of Western culture that are considered modern. This mixture of Turkish, Islamic and Western civilizations has colored the identity of the Turkish people.

In this paper, the author uses diplomacy theory to discuss the Turkish movement in its attempt to take over the Hagia Sophia to become a house of worship for Muslims there. Diplomacy itself comes from the word "diploum" which in Greek means "to fold", where this is every way that is attempted or taken to communicate with each other to carry out actions in the form of politics or law through several representatives who are appointed and get authorization.

In practice, diplomacy exists as an action to safeguard the interests of the state, including maintaining the position and dignity of the state among foreign countries, especially among countries that are still in one region. The objectives of this diplomacy include acquisition, preservation, augmentation, and proper distribution.

In the process of compiling this journal, the author uses several literature studies in the form of journals as a framework that is still related to the discussion of Turkey, especially the discussion of secularism and the domination of Islam. The first journal is entitled "Turkey Between Secularism and the Aroma of Islam; A Study on the Thought of Niyazi Berkes" by Imron Mustofa. This journal generally discusses the journey of Turkey as a country that is dominated by powers from the west and the east which also colors the

${ }^{3}$ Miriam Budiardjo, Dasar-Dasar Ilmu Politik (Jakarta, DKI Jakarta: PT Gramedia Pustaka Utama, 2009).

4Tabrani ZA, "PERUBAHAN IDEOLOGI KEISLAMAN TURKI (Analisis Geo-Kultur Islam Dan Politik Pada Kerajaan Turki Usmani)," JURNAL EDUKASI: Jurnal Bimbingan Konseling 2, no. 2 (February 2016): p. 130, https://doi.org/10.22373/je.v2i2.812 
conditions of the people there, starting from the occurrence of state reforms due to religion.

The second journal is entitled "The History of Islamic Development in Turkey" by Fathur Rahman, where this journal contains a comprehensive discussion of the influence of Islam in Turkey which begins with a discussion of the history of the birth of Turkey and the early development of Islam in Turkey itself. Then the language continues into the history of the birth of the Ottoman Empire, a story of expansion with a passion for expanding Islamic followers in Turkey to their heyday. Finally, this journal ends with a discussion of Islam in Turkey during the current reform era.

Third, the journal that the writer considered while working on this paper was entitled "Recep Tayyeb Erdogan's Political Thought (Study of Secular Versus Islamic Political Struggles in the Turkish Revolution)" by Syaeful Bahri which discusses the background of Erdogan's life as a leader of Turkey, which in fact Erdogan grew up in an environment that is thick with Islamic teachings so that it affects all actions and decisions he takes, both for himself and for the country he leads. This journal also explains Erdogan's political career from the start of his participation to leading the AKP and serving as president of Turkey until now.

The research method that the author uses this time is a qualitative descriptive research method using secondary data collection techniques, namely the data obtained from library research activities in the form of books, journals, theses. ${ }^{5}$ Qualitative research is research that is used to investigate, discover, describe, and explain the quality or features of social influences that cannot be explained, measured or described through a quantitative approach, and the results of qualitative research also emphasize meaning rather than generalization. ${ }^{6}$

Apart from being sourced from books, journals and theses, other sources as other supporting data also include articles, print and electronic media, as well as websites whose entire data has been arranged in such a way, has been sorted and selected from relevant sources so that the data in this paper remain accurate with high validity and the end result can be justified.

\section{History of the Ottoman Turks}

\footnotetext{
55ugiyono, Metode Penelitian Pendidikan (Pendekatan Kuantitatif, Kualitatif, R\&D) (Bandung, Jawa Barat: Alfabeta, 2014).

${ }^{6}$ Saryono, Metode Penelitian Kualitatif (Bandung, Jawa Barat: Alfabeta, 2010).
} 
In $990 \mathrm{AD}$, the Turks from Central Asia converted to Islam and began to migrate to Anatolia or Asia Minor. Then continued in 1071, the Byzantine region which is Asia Minor (now Turkey), was captured by the Seljuks after experiencing defeat in the battle of Manzikert. Then the Turks founded the Seljuk Sultanate.

The King of Byzantium then wanted to restore Byzantine rule in the Middle East which was captured by the Muslims. Finally he conveyed this news to Pope Urban II that the Seljuk Sultanate was trying to blackmail Christian pilgrims who came to Jerusalem. This information was intended to encourage the Europeans to attack the Seljuk sultanate.

The meeting in Clermont, France, then succeeded in gathering many kings from Europe and issued a decision to hold a Crusade. Long story short, then the Crusades broke out and occurred eight times until it claimed a large number of lives and became one of the bloodiest war events ever to take place in the world. The Seljuk regions also became divided, but the Muslims won contested areas. The Seljuk Turkish Sultanate was later replaced by the Ottoman Empire in 1288.

Ustman founded the Ottoman Empire where the people came from the Central Asia region with the capital city of Busra. The Ottoman Turks then defeated the Europeans a lot and finally conquered Constantinople, so that the history of Byzantium was over there. The Ottoman Empire then changed the name of Constantinople to Istanbul. In this year the Hagia Sophia church was converted into a mosque.

In 1571, all European troops joined to fight against the Ottoman Turks so that the Ottoman Turks lost against the combined European forces. The Ottoman Turks then experienced a setback since this war because the empress of the sultan often interfered in the appointment of their sons as sultans. This is the main cause of Turkey's decline. In 1861, when Sultan Abdul Hamid was in power, modernization was carried out to prevent the decline of Turkey. Then in 1861 to 1876, Sultan Abdul Aziz continued the reform and modernization of Turkey.

Various events after that happened and colored this nation. In 1869, the modernization movement was continued by Fuad Pasha, Ali Pasha, and Namik Pasha as modernization was marked by the establishment of a university, namely the University of Constantinople, and the establishment of a national bank. Then in 1896, Sultan Hamid II, who led Turkey at that time, founded the young Turkish movement by reorganizing the state in a modern way, instilling 
nationalism, and affirming the Turkish nationality with the motto of one country, one nation and one Turkish language.

In 1919-1921, Mustafa Kemal Pasha was considered a hero by some Turkish people because he managed to hold back European forces who wanted to destroy Turkey. Finally he was appointed president and the title Kemal Attaturk (Father of Turkish Development). He also had the chance to abolish the religious system in his government and promote secularization and westernization. Turkey eventually became a secular state. ${ }^{7}$

\section{Turkey The Secular State}

After the collapse of the sultanate and Turkey becoming a republic, this country adopted secularism. Turkey as a secular state means that they accept the existence of religion, but do not make that religion the basis of legitimacy in running its government. In the Big Indonesian Dictionary, secularism is a philosophical notion or view that holds that morality does not need to be based on religious teachings. Meanwhile, "secularization" is interpreted as a way of life that separates religious affairs from state affairs.

The roots of secularism come from the European continent which is caused by the arrogance and domination of the church as well as its feudalistic actions which later gave birth to a discriminatory nature against the people, so that injustice was felt by European society until the Renaissance era. In fact, this golden age of Europe actually had a big impact, such as the reduction of church domination, the birth of anti-religious seeds, and the emergence of a popular movement that wanted to fight for a better life through liberation efforts against unjust conditions. Some of these impacts later became the forerunner of the birth of secularism.

Departing from that thought, actually the Islamic world is also not always homogeneous, including in Turkey, because each country certainly has fundamental differences even though the majority of the population is Muslim, as happened in the life of Turkish society. In this case, even though the majority of the population of Turkey embraces Islam, they still have the right to

7 Muhammad Doddy A.B., Menguasai IPS: Sistem Kebut Semalam, 6th ed. (Depok, Jawa Barat: Pustaka Gema Media, 2013). 
determine their own way of life, including having the right to be free by not involving religious matters too much in their daily lives. ${ }^{8}$

Turkey is known as a nation that has led the Islamic world for 7 centuries, from the early 13th century to the fall of the Ottoman Turks in the early 20th century. The phenomenon of Turkish community life became interesting when Turkey in 1923 officially transformed into a secular state, where Islam, which had functioned as a religion and system of community and state life, began to be replaced by the Western system. ${ }^{9}$

In addition, another reason for the development of secularism in Turkey is that the existence of extreme nationalism also eventually grows in the social life of the Turkish people, especially the younger generation, where a strong feeling of national identity and national pride, which sometimes generates superiority, which psychologically counterbalances desire to follow Europe.

Kemal Ataturk, who is known as the father of Turkish development, carried out the reform of Turkey into a new secular Turkey by reforming Turkey from a Sultanate to a Republic. Kemal also rationalized religion in order to separate religious affairs from state affairs and at the same time end the power of Shaykhul Islam as a religious institution in the political, social and cultural realms.

He considered the dominant existence of religion in the affairs of state administration, especially in the political arena, to be the cause of decline for religion, namely Islam itself. Referring to the superiority of the western world, Kemal was determined that Turkey must also be a developed country with high civilization, therefore, secularism must be applied to modernize the life of Turkish society.

In addition, based on this intention, Kemal also changed the Arabic script and replaced it with Latin script. In his leadership era, the educational aspect was also completely overhauled by freeing schools from religious elements and placing educational institutions under the supervision of the Ministry of Education. Furthermore, he also reformed the law by replacing the

\footnotetext{
8Isputaminingsih, “Sejarah Islam: Kasus Sekularisme Turki," Sejarah Islam:

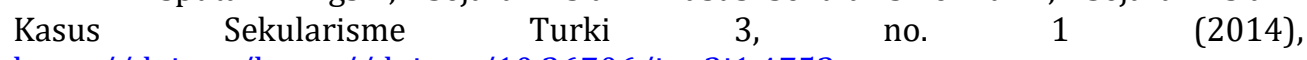
https://doi.org/https://doi.org/10.36706/jc.v3i1.4753

${ }^{9}$ Imron Mustofa, Turki Antara Sekularisme Dan Aroma Islam; Studi Atas $\begin{array}{llllll}\text { Pemikiran Niyazi } & \text { Berkes 6, no. } & 1 & \text { (2016), }\end{array}$ http://ejournal.kopertais4.or.id/susi/index.php/elbanat/article/view/2893
} 
Sharia Law by enacting the Swiss Civil Code in Turkey, and maintaining secularism there with the help of military forces under his control.

\section{Hagia Sophia}

The Hagia Sophia is an important building that is considered to be the "huge structure" of Byzantine architects and is one of the world's best remains. This church was founded by the Jutstinian emperor I. Hagia Sophia is called Ayasofya in Turkish, and Sancta Sophia in Latin. Hagia Sophia also means a holy place for God. Hagia Sophia was also known as the Church of the Holy Wisdom and the Church of the Divine Wisdom. ${ }^{10}$

The Hagia Sophia is an enormous architectural marvel in Istanbul, Turkey, which was originally built as a Christian basilica nearly 1,500 years ago. The role of the Hagia Sophia is undoubtedly in the history of Istanbul as well as the world, because this magnificent building has indirectly become a symbol of matters relating to international politics, religion, art and architecture.

Hagia Sophia was first built as a cathedral for Christians in 537 AD. The first religious service at the "new" Hagia Sophia was held on 27 December 537. The building was converted into a mosque in 1453. Then when the Ottoman Empire became the Republic of Turkey, Turkey's first president, Mustafa Kemal Ataturk, turned the Hagia Sophia into a museum in 1935.

In the early days of its development, the Hagia Sophia's design was very unique and complex. From its opening, the Hagia Sophia combines traditional design elements such as an orthodox basilica with a large domed roof. The arch supporting the dome is covered with a mosaic of winged angels called hexapterygons. In an attempt to create a large basilica representing the entire Byzantine Empire, then Emperor Justinian announced that all the provinces under his rule were sending architectural works to be used in its construction.

The grandeur of this "iconic" place of worship is also evident from the inside of the Hagia Sophia which is lined with a large marble slab supposedly designed to imitate moving water. Furthermore, the supporting materials for this mosque are also considered luxurious because there are 104 columns in

\footnotetext{
10Dewi Adhitya S. Koesno and Abdul Hadi, "Lima Fakta Seputar Hagia Sophia: Museum Yang Kini Menjadi Masjid," tirto.id (Tirto.id, July 14, 2020), https://tirto.id/lima-fakta-seputar-hagia-sophia-museum-yang-kini-menjadi-masjidfQRL (accessed January 16, 2021)
} 
the Hagia Sophia which are apparently imported directly from the Temple of Artemis in Ephesus, as well as from Egypt. ${ }^{11}$

The center dome of the Hagia Sophia rests on a window ring and is supported by two semi domes and two curved openings to create a large nave, the walls of which were originally covered with intricate Byzantine mosaics of gold, silver and glass, giving the mosque a colorful interior. colorful. Long story short, because Greek Orthodox was the official religion of Byzantium, the Hagia Sophia was considered the central church as well as the place where the new emperor was crowned. The ceremony takes place in the center, where there is an Omphalion (navel of the earth), a large circular marble section of colorful stone with an interlocking circular design.

The Hagia Sophia played an important role in the culture and politics of the Byzantine era during the first 900 years of its existence. However, during the Crusades, the cities of Constantinople and Hagia Sophia came under Roman control for a short time in the 13th century. The Hagia Sophia was badly damaged during this period, but was repaired again when the Byzantine empire once again took control of the surrounding city.

After Constantinople fell into the hands of the Ottoman Empire and the city changed its name to Istanbul, everything also changed to Islamic nuances. Since Islam is the main religion of the Ottoman, the Hagia Sophia was renovated into a mosque. As part of the conversion, the Ottomans covered many original Orthodox themed mosaics with Islamic calligraphy. The panel or medallion, which hangs in the column in the center, displays the names Allah, the Prophet Muhammad, the first four Caliphs and the Prophet's two grandchildren.

The mosaic on the main dome, believed to be an image of Christ, is also covered in gold calligraphy. A mihrab or nave is installed on the wall, as is tradition in mosques, to indicate the direction to Mecca, one of Islam's holiest cities. Four towers were also added to the original building during this period, partly for religious purposes (for the muezzin's call to prayer) and partly to

\footnotetext{
${ }^{11} \mathrm{Ni}$ Luh Made Pertiwi F., "Sejarah Hagia Sophia, Perjalanan Kembali Menjadi Masjid," KOMPAS.com (Kompas.com, July 11, 2020), https://travel.kompas.com/read/2020/07/11/161629927/sejarah-hagia-sophiaperjalanan-kembali-menjadi-masjid (accessed January 16, 2021)
} 
strengthen the structure after the earthquake that hit the city around that time. ${ }^{12}$

In 1935, the Hagia Sophia was turned into a museum and the mosaic restoration was carried out by removing the plaster cover. Therefore, before President Recep Tayyip Erdogan officially turned it into a mosque, the Hagia Sophia was considered a symbol of unifying religion between Islam and Christianity. In Hagia Sophia, even the calligraphy of Allah and Muhammad SAW are placed parallel to the paintings of the Virgin Mary and the baby Jesus.

Hagia Sophia has been recognized as one of the UNESCO World Heritage sites included in the historical area of Istanbul since 1985, where this area includes the main historical buildings and sites of the city. With the change in the face and function of Hagia Sophia, from a museum to a mosque, from being a symbol of peace and neutrality, it is now proof that no peace is truly eternal.

\section{Erdogan's Islamization Diplomacy}

Turkey in the end chose a pluralist character, which is what ultimately led to secularism by changing the system of government from the Turkish Sultanate to the Republic of Turkey, where the basis of secular government does not mean completely contradicting religion, but Turkey does not really involve or make that religion as a basis of legitimacy in running the government. ${ }^{13}$

However, there are still some conservative Muslims who oppose the secular system of the government. On closer inspection, we can conclude that Turkish history is filled with Islamic touches. But ironically, in the life order of Turkish society today, they are seen as "forced" to accept secularism as a new order in carrying out the life of the nation and state, and even tend to sink into the abyss of secularism. This problem certainly needs to be analyzed, considering that Turkey in the past was filled with the glory of Islam.

Recep Tayyip Erdogan has served as president of Turkey since 2014, having previously served as prime minister of Turkey for 11 years. In the arena of Turkish politics, Erdogan is considered a respected figure, because he became one of the pioneers who generated Islamic influence in the country. Erdogan founded the AKP (Adalet Ve Kalkinma Partisi or the Justice and

\footnotetext{
${ }^{12}$ History.com Editors, "Hagia Sophia," History.com (A\&E Television Networks, January 12, 2018), https://www.history.com/topics/ancient-greece/hagia-sophia (accessed January 17, 2021)

13 Isputaminingsih, Sejarah Islam: Kasus Sekularisme Turki, Vol. 3, no. 1 (2014), https://doi.org/https://doi.org/10.36706/jc.v3i1.4753
} 
Development Party) in 2001, which is an Islam-based party. In its journey, this party then won the sympathy of the people and won several elections. AKP's ranks of politicians also occupy strategic positions, ranging from dominating parliament, occupying the seat of prime minister, to presiding as president, including Erdogan himself.

Erdogan's Islamization began when he was still prime minister, at which time Erdogan promoted a new education program, namely by repromoting teaching based on the Islamic holy book, the Al-Quran in state schools in Turkey, and freeing reuse of use. hijab for women in educational institutions such as in the campus area. This policy certainly adds to the impression that his government is peaceful and pro-people.

In his life, Erdogan himself grew up in an environment that was very thick with Islamic nuances. As a Muslim, he made the Prophet Muhammad SAW a role model. Erdogan also mentioned several Islamic political fighters such as Said Nursi, Fethullah Gulen and Necmettin Erbakan as role models for his career. These three figures are the most influential figures in the history of the Islamic political movement in Turkey during their clash with the ideology of secularism. ${ }^{14}$

The three of them were called the ranks of the most influential figures because after the dissolution of the Ottoman sultanate by Mustafa Kemal, Said Nursi with his Nursiyah movement tried hard to restore Islamic law into state life, where this effort was intended to withstand the increasingly widespread flow of secularism and dominate Turkish lands. As a Muslim as well as a politician, his movement focuses on discussing faith and enhancing people's beliefs according to Islamic teachings.

The next tough task to restore the glory of Islam in Turkey is carried out by Fethullah Gulen. Gulen is a charismatic cleric figure, who jumped into politics because he was inspired by Said Nursi's struggle. With his Hizmet movement or "The Fethullah Gulen Movement", he and his sympathizers work hand in hand to serve the community by focusing on spreading peace both within individuals and groups to target universal lasting peace throughout the country, one of which is through the path of education based on the teachings of Sufism.

\footnotetext{
${ }^{14}$ Syaeful Bahri, Pemikiran Politik Recep Tayyeb Erdogan (Studi Terhadap Pergulatan Politik Sekular Versus Islam Dalam Revolusi Turki) 4, no. 2 (Desember 2017), https://doi.org/https://doi.org/10.7454/meis.v4i2.46
} 
This type of education prioritizes the application of Sufism values such as taqwa, repentance, zuhud, sincerity, muraqabah, istiqamah, tawakkal, tawadu ', gratitude, ihsan, and patience, as well as love for the Divine, where this love can then also be transformed into a sense of love for fellow human beings, and in the end will foster a harmonious life even though there are many differences between humans themselves.

The third figure who became Erdogan's role model was Necmettin Erbakan. Erbakan is the founder of several Islamic-based parties which often become rivals of the Turkish military because they are considered to disturb the "tranquility" of the flow of secularism there. Erbakan's political movement tends to be lenient, where even in the face of a military coup, he persisted in controlling the Islamist group he led by applying an evolutionary cultural approach instead of a massive and aggressive movement, even though he was basically a typical human with a strict, authoritarian nature. but still careful and precise in making every decision in his political career.

Erdogan also seems to be a nationalist who really loves his country, especially everything about the Ottoman Sultanate. Because of this, he often reintroduced several cultures and traditions from the Ottoman heritage, one example of which was wearing imperial-style clothing to welcome state guests, which many later considered he looked more like part of "blue blood" than family members and descendants. the sultan himself. The influence of the Ottoman Empire was so ingrained in him that he was later said to want to spread neo-ottomanism throughout Turkey. Neo-ottomanism is actually not only limited to the visual scope of culture, but is also related to political entities and the future of Turkey. ${ }^{15}$

The neo-ottomanism spread by Erdogan, along with his party, the AKP, will then be used as a powerful weapon to unite pieces of national consensus to remind and awaken all Turkish people that their nation once controlled such a vast land, from Europe, the Middle East, Africa, even the Balkans. ${ }^{16}$ This covert but visionary agenda will be used in various aspects such as political, diplomatic, economic and socio-cultural interests to reinforce the vision and

${ }^{15}$ Ahmad Junaidi, Kebijakan Politik Recep Tayyib Erdogan Dan Islamisme Turki

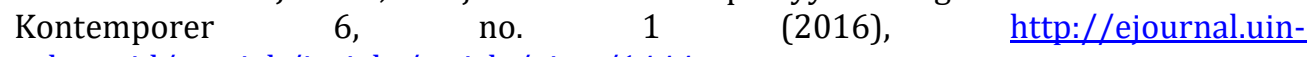
suka.ac.id/syariah/inright/article/view/1444

16Taspinar Ömer, Turkey's Middle East Policies: Between Neo-Ottomanism and Kemalism 10 (2008), https://carnegieendowment.org/files/cmec10 taspinar final.pdf 
mission related to Turkey's foreign policy in order to embrace the legacy of great Ottoman power as a Turkish national identity. ${ }^{17}$

Erdogan's diplomacy with his spirit of Islamization led to an attempt to transfer the function of the Hagia Sophia from a museum to a mosque through approval at the Turkish High Court. ${ }^{18}$ Precisely in mid-2020, the Turkish High Court canceled the cabinet decree in 1934 and the State Council announced that the Hagia Sophia was indeed owned by a foundation founded by Ottoman Sultan Mehmet II and given to the community as a mosque, and had been legally validated.

Erdogan emphasized that Turkey's decision must be respected, despite the many criticisms both coming from their own country and from foreign parties, because he argued that the conversion of the Hagia Sophia in the past from a mosque to a museum was a decision that was actually painful for the Turkish nation, considering the country's history was filled with domination of Islam. For Erdogan, his Islamization determination is unanimous, and his control over Turkey as President, the highest competent authority, is inviolable, so domestic and foreign criticism of the decision are also meaningless in the eyes of Turkish law.

Of course, this effort has drawn reactions from various parties, considering that the Hagia Sophia is a symbol of the two great beliefs on earth, namely Islam and Christianity. This change of function in the form of mosque diplomacy ${ }^{19}$ has also not escaped the international spotlight, which has led to criticism from various parties such as the Pope, the Catholic religious leaders themselves and also from the UNESCO side as a related institution.

UNESCO deeply regrets this incident because the Hagia Sophia is part of the historical area of Istanbul which is a property written in the UNESCO World

${ }^{17}$ Tony Firman and Ivan Aulia Ahsan, "Ambisi Neo-Ottomanisme Erdogan Berbahaya Bagi Kestabilan Timteng?," tirto.id (Tirto.id, September 3, 2020), https://tirto.id/ambisi-neo-ottomanisme-erdogan-berbahaya-bagi-kestabilantimteng-f2Ai (accessed February 20, 2021)

18Danur Lambang Pristiandaru, "Pengadilan Turki Beri Jalan Hagia Sophia Jadi

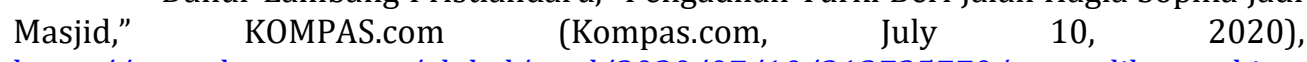
https://www.kompas.com/global/read/2020/07/10/212725770/pengadilan-turkiberi-jalan-hagia-sophia-jadi-masjid?page=1 (accessed January 16, 2021)

${ }^{19}$ Sovie Dina, "Diplomasi Masjid Ala Turki" Duta.co Berita Harian Terkini, August 11, 2020, https://duta.co/diplomasi-masjid-ala-turki (accessed January 16, 2021) 
Heritage List. ${ }^{20}$ Its status as a museum is the best option, because this neutrality reflects the universal nature of its heritage, and makes it a powerful symbol for dialogue. However, since the official decision was released, now things have changed and have disappointed many parties.

Apart from all the controversial decisions regarding the transfer of function of Hagia Sophia, Erdogan's Islamic politics reflects his actions that prove that Turkey is a sovereign state and has the right to fight for its fate and emphasizes that they can also prioritize the interests of Muslim citizens. ${ }^{21}$ However, Erdogan still allowed the Hagia Sophia to be visited by anyone. Erdogan's maneuvers and courage shows Turkey's strength in the international world also reflects the national interests and the power of the country itself, where Turkey cannot be underestimated by other countries.

In addition, historically, the majority of Turks are Muslim, of course there was a lot of support that flowed when the Hagia Sophia officially became a mosque. Moreover, Turks always identify as Muslim. The thing to remember is that in this contemporary era, the development of Islam is interpreted as an instrument for government policy. Islam is considered a vital component in the cultural content of the nation and is mobilized to increase national unity. ${ }^{22}$

\section{Conclusion}

Undoubtedly, Turkey's various policies this time reflect their increasingly courageous diplomacy under Erdogan's leadership with his high Islamic political fervor. Even though Turkey is currently considered an enemy by some countries because its policies have become very controversial, when we return to the concept of international relations, this reflects that a sovereign nation has the right to determine its own destiny and conduct international politics in accordance with their national interests.

In this case, the leader of Turkey, namely President Erdogan as a decision maker or the decision maker, has a big part in the efforts of the Hagia Sophia to become a mosque. His political career for a dozen years leading

20“UNESCO Statement on Hagia Sophia, Istanbul,” UNESCO, July 13, 2020, https://en.unesco.org/news/unesco-statement-hagia-sophia-istanbul (accessed January 17,) 2021

${ }^{21}$ Elba Damhuri, "Diplomasi Keren Erdogan Soal Masjid Hagia Sophia," Republika Online (Republika Online, July 12, 2020), https://republika.co.id/berita/qdc7mi440/diplomasi-keren-erdogan-soal-masjidhagia-sophia (accessed January 17, 2021)

${ }^{22}$ Fathur Rahman, Sejarah Perkembangan Islam Di Turki 10, no. 2 (2018), https://doi.org/https://doi.org/10.47945/tasamuh.v10i2.74 
Turkey made him dare to take big steps for the welfare of the people, especially thinking rationally about the liberation of buildings in the form of places of worship which is the right of all Muslims in Turkey.

\section{References}

A.B., Muhammad Doddy. Menguasai IPS: Sistem Kebut Semalam. 6th ed. Depok, Jawa Barat: Pustaka Gema Media, 2013.

Bahri, Syaeful. Pemikiran Politik Recep Tayyeb Erdogan (Studi terhadap Pergulatan Politik Sekular Versus Islam dalam Revolusi Turki) 4, no. 2 (December

2017). https://doi.org/https://doi.org/10.7454/meis.v4i2.46

Budiardjo, Miriam. Dasar-Dasar Ilmu Politik. Jakarta: PT Gramedia Pustaka Utama, 2009.

Damhuri, Elba. “Diplomasi Keren Erdogan Soal Masjid Hagia Sophia.” Republika Online. Republika Online, July 12, 2020. https://republika.co.id/berita/qdc7mi440/diplomasi-keren-erdogansoal-masjid-hagia-sophia.

Dina, Sovie. “Diplomasi Masjid Ala Turki." Duta.co Berita Harian Terkini, August 11, 2020. https://duta.co/diplomasi-masjid-ala-turki.

Emre, Nilay Yilmaz. Church of Divine Wisdom: Hagia Sophia 24, no. 3 (2014). http://www.turkishneurosurgery.org.tr/pdf/pdf_TTN 1319.pdf

F., Ni Luh Made Pertiwi. "Sejarah Hagia Sophia, Perjalanan Kembali Menjadi Masjid.” KOMPAS.com. Kompas.com, July 11, 2020. https://travel.kompas.com/read/2020/07/11/161629927/sejarahhagia-sophia-perjalanan-kembali-menjadi-masjid.

Firman, Tony, and Ivan Aulia Ahsan. "Ambisi Neo-Ottomanisme Erdogan Berbahaya Bagi Kestabilan Timteng?" tirto.id. Tirto.id, September 3, 2020. https://tirto.id/ambisi-neo-ottomanisme-erdogan-berbahayabagi-kestabilan-timteng-f2Ai

History.com Editors. "Hagia Sophia.” History.com. A\&E Television Networks, January 12, 2018. https://www.history.com/topics/ancientgreece/hagia-sophia

Isputaminingsih. Sejarah Islam: Kasus Sekularisme Turki 3, no. 1 (2014). https://doi.org/https://doi.org/10.36706/jc.v3i1.4753

Jackson, Robert, and Georg Sorensen. Pengantar Studi Ilmu Hubungan 
78 | AJIS : Academic Journal of Islamic Studies, vol. 6, no. 1, 2021

Internasional: Teori Dan Pendekatan. 5th ed. Yogyakarta, Daerah Istimewa Yogyakarta: Pustaka Pelajar, 2016.

Junaidi, Ahmad. Kebijakan Politik Recep Tayyib Erdogan dan Islamisme Turki Kontemporer 6, no. 1 (2016). http://ejournal.uinsuka.ac.id/syariah/inright/article/view/1444

Koesno, Dewi Adhitya S., and Abdul Hadi. "Lima Fakta Seputar Hagia Sophia: Museum Yang Kini Menjadi Masjid.” tirto.id. Tirto.id, July 14, 2020. https://tirto.id/lima-fakta-seputar-hagia-sophia-museum-yang-kinimenjadi-masjid-fQRL

Mustofa, Imron. Turki Antara Sekularisme dan Aroma Islam; Studi atas Pemikiran Niyazi Berkes 6, no. 1 (2016). http://ejournal.kopertais4.or.id/susi/index.php/elbanat/article/view/ $\underline{2893}$

Ömer, Taspinar. Turkey's Middle East Policies: Between Neo-Ottomanism and Kemalism 10

(2008).

https://carnegieendowment.org/files/cmec10 taspinar final.pdf

Pristiandaru, Danur Lambang. "Pengadilan Turki Beri Jalan Hagia Sophia Jadi Masjid.” KOMPAS.com. Kompas.com, July 10, 2020. https://www.kompas.com/global/read/2020/07/10/212725770/pen gadilan-turki-beri-jalan-hagia-sophia-jadi-masjid?page=1

Rahman, Fathur. Sejarah Perkembangan Islam di Turki 10, no. 2 (2018). https://doi.org/https://doi.org/10.47945/tasamuh.v10i2.74

Saryono. Metode Penelitian Kualitatif. Bandung, Jawa Barat: Alfabeta, 2010.

Solihat, Ade. "Kemalisme, Budaya dan Negara Turki". http://www.fib.ui.ac.id

Sugiyono. Metode Penelitian Pendidikan (Pendekatan Kuantitatif, Kualitatif, Dan R\&D). Bandung, Jawa Barat: Alfabeta, 2014.

"UNESCO Statement on Hagia Sophia, Istanbul." UNESCO, July 13, 2020. https://en.unesco.org/news/unesco-statement-hagia-sophia-istanbul

ZA, Tabrani. "PERUBAHAN IDEOLOGI KEISLAMAN TURKI (Analisis Geo-Kultur Islam

Dan Politik Pada Kerajaan Turki Usmani)." JURNAL EDUKASI: Jurnal Bimbingan Konseling 2, no. 2 (2016): 130. https://doi.org/10.22373/je.v2i2.812 